\title{
The Academic Job Crisis: A Unique Opportunity, Or Business as Usual?
}

\begin{abstract}
Robert Haro's article in the March 1972, issue ("Change in Academic Libraries") warns that the profession is slow to accept suggestions from outside sources, but perhaps this article can best come from someone who stands midway between teaching and library service.

The paper not only evokes the dimensions of the academic job crisis, and the resulting opportunity for library recruitment, but calls attention to the danger of permitting the librarians' own job market to be overrun by candidates who may not have a genuine commitment to library service. As a "think-piece" it is deliberately general and suggestive, with footnotes and statistics kept to a minimum.
\end{abstract}

Editor's Note-Subject specialists, some have contended, do not require a general founding in the principles of librarianship to succeed as librarians. Library directors have been overheard to observe that a subject $\mathrm{Ph} . \mathrm{D}$. minus the MLS actually enhances their library's status within the local academic community. But now that the job market has changed radically, are these views still held, or for that matter had they ever gained broad acceptance?

Mr. Moffett's piece raises several intriguing questions. Has the attitude toward the recruitment of individuals possessing subject Ph.D.'s changed? Moffett views the current job market as an opportunity for the library profession and, indeed, his perceptions may be correct. The editors believe that the issue merits a hearing. We would like to hear from our readers regarding their perceptions on the role of subject

The author, who received his doctorate in English history at Duke University, is an assistant professor of history at the University of Massachusetts at Boston and a student in the school of library science of Simmons College. specialists. For example, should a subject specialist Ph.D. be required to obtain a library degree as a demonstration of professional commitment? Readers are invited to communicate their views to the editors.

A $\mathrm{ED}$, a crisis in the academic marketplace long in the making is presenting librarianship-and especially, but not exclusively, academic librarianship-with an opportunity for selective recruiting that to all appearances is as unanticipated as it is unprecedented in scope. It remains to be seen just what the profession will make of it.

To be sure, the number of job openings for librarians is itself diminishing. ${ }^{1}$ Nonetheless, the need for better qualified professionals persists. Indeed, it is sustained by a compelling interest in fostering the development of the socalled "new breed" of librarians, by the increasing variety of roles librarians are being called upon to play, and by the continuing effort to upgrade the status 
of the profession generally. The profession of librarianship will be well served by bringing into its ranks men and women who have already done advanced work in subject areas, who have had considerable experience in graduate level research, and who have significantly displayed proficiency in communication skills. But while not long ago it was thought an ideal goal for academic librarians to have an M.A. in a subject field, it now seems possible to secure a substantial infusion not only of M.A.s but of Ph.D.s trained for, and in many cases experienced in, college level teaching.

The causes of the current oversupply of Ph.D.s are too well-known to describe in detail here, but they are basically twofold: overproduction by graduate schools on the one hand, coupled with an actual attrition of job openings on the other, as the projected expansion of undergraduate colleges has not only failed to continue, but is being drastically cut back.

The surplus affects every major discipline, whether in science, social science, or the humanities. And it is severe. At last year's American Historical Association convention, for example, there were 2,300 applicants for only 155 jobs. With graduate schools still dumping approximately 1,000 history Ph.D.s on the market annually, the prospect for next year is even worse. Those who have studied the crisis foresee little chance of any meaningful increase of jobs for many years to come. ${ }^{2}$

For these would-be academics the possibilities for securing alternative employment commensurate with their credentials are becoming extremely thin. The idea that secondary schools and community colleges might absorb many of them has proven unrealistic. Opportunities which once existed in government and industry have virtually disappeared. Moreover, there is a tendency on the part of many prospective em- ployers to regard persons with a Ph.D. as overtrained, overspecialized, and very unlikely to be either contented or efficient in nonacademic work. Thus, as Lawrence Stone points out, many men and women with a doctorate are finding that they have apparently disqualified themselves from almost every jobapart from the four-year college-that society has to offer.

What is more, a large number of the surplus Ph.D.s on today's market are by no means recent graduates. A growing percentage are experienced university teachers who have run afoul of increasingly restrictive tenure quotas. Indeed, with mounting pressure to economize, many institutions are showing themselves unable to resist the expedient of hiring relays of junior staff who are let go after three to six years when their tenure decisions fall due. The classroom experience of. such teachers may offer them some advantage over the more recent graduates in securing new employment, but little guarantee of maintaining their salary level in a tightening market. The ones lucky enough to find employment are doubly lucky if their courses reflect their fields of special interest. Moreover, within a short time they have to run the tenure gauntlet again, with no more security than before.

In this unhappy state of affairs, it is not surprising that frustrated teachers are increasingly turning to librarianship for alternative academic careers, drawn naturally by reason of affinity as well as by the operation of supply and demand. Still others would be attracted if they were made more fully aware of the range of options in library service open to them. And undoubtedly the same holds true not only for the surplus Ph.D.s but for all those currently frozen out of the market for teachers.

But will the profession be content to take a passive role? It has been observed that the "insistence of librarians that 
they want to recruit a new breed of young librarians would ring truer if they were doing more about it." ${ }^{3}$ What, for example, are they doing now at graduate schools of arts and sciences across the land to publicize career opportunities at the point where receptive doctoral candidates may be most readily recruited-namely, the office of the graduate adviser in the individual department? Are academic librarians actively engaged in presenting the challenges of their profession to the graduate students of their own universities? When the annual conventions of the various disciplines meet in the course of the coming year, thronged as usual with anxious job-seekers, will spokesmen for the academic library be there as well? And will they project a sense of something more demanding and satisfyingas well as more realistic-than what has been communicated by the dull, clichéridden recruiting literature of the past several years?

Is it possible that despite a reputation for being reluctant to respond quickly to changing needs, library schools will bestir themselves to facilitate the retraining of people originally destined, as they thought, for conventional teaching positions? Have they in fact thought out the kinds of fundamental adjustments required of a person who attempts to make such a shift? Or will it be business as usual in terms of both recruitment and curricula? Will the availability of loans and scholarships take into account the special problems of advanced degree holders who are not normally eligible for many types of existing grants?

But perhaps most importantly of all, especially if the interest in library careers becomes as pronounced as this writer thinks it may, will the library schools and employers exercise intelligent discrimination in accepting prospective candidates from the ranks of the harried scholars? A Ph.D. is by no means a surety that the holder will make a useful librarian, and the degree should not get in the way of thoughtful and perceptive appraisal. The glutted academic job market, after all, was fed in part by the input of substandard doctorates. It would be doubly ironic if, as the librarians' own job market shrinks, positions are filled with job-hungry refugees who, despite an impressive array of degrees, will debase, not enrich, weaken, not invigorate the "new breed" of librarians. For undoubtedly there will be those who see librarianship primarily as a convenient meal ticket which will claim a minimum of creative energy while permitting them to carry on research in their subject fields.

Still, that caveat aside, the opportunities for recruitment should rouse the imagination of all those who have agonized over the problem of attracting professionals with genuine scholarly interests, a commitment to education, and the temperament for working actively with people and ideas which truly excellent library work requires.

For it is not only that there is a surplus of people hungry for jobs, but that so many of them are ideally suited for service in the academic library. They are likely, at the very outset, to be enthusiastic about the potential of the library as a teaching facility. It is even possible that they would help insure more meaningful activity in that respect and fewer empty phrases. Their teaching background may better enable them, too, to take a useful role as librarians in the reshaping of the curriculum, in leading interdisciplinary ventures, and in promoting independent studies. One may speculate that they would significantly help bridge the gap which so often separates librarians and regular faculty members. They will surely reinforce the drive to secure the advantages of faculty status, with all that that entails.

To suggest this, of course, is to pro- 
pose nothing new. Librarians have always drawn new colleagues from the classroom. The novelty lies in the unprecedented numbers of prospective recruits of outstanding caliber, and the urgency of taking prompt and deliberate action to turn the crisis to the maximum benefit of the profession.

Not long ago this journal published some remarks of President Lyman of Stanford which warned that the coun- try's response to the oversupply of Ph.D.s was probably going to be determined more by "the function of political attitudes and the resulting availability or unavailability of money" than by "scholarly or institutional choice and ambitions." 4 This need not be true of the response of librarians. If it proves to be the case, however, the profession may well have squandered a momentous opportunity.

\section{REFERENCES}

1. Although the rate of decline in library openings in 1971 was described as only moderate by Carlyle Frarey and Carol Learmont in "Placement and Salaries, 1971: A Modest Employment Slowdown," Library Journal 97:2154-2159 (June 1972), disappointed job-seekers at last summer's ALA convention were convinced it had accelerated drastically (New York Times, July 2, 1972, p. 12).

2. John L. Shover and Lawrence Stone, "Jobs for Historians and the Role of the AHA," AHA Newsletter 10:19-27 (March 1972). The plight of Ph.D.s in history is especially relevant because no discipline is more library-oriented. A recent employment information bulletin analyzes data for the immediate hiring period supplied by six hundred and ninety-two four-year colleges and universities (or nearly 60 percent of the institutions from which information was solicited). In the schools reporting-and not counting an undetermined number of job aspirants who are not new entrants into the market-there were some 2,711 persons known to be seeking immediate employment (including M.A.s, doctoral candidates, and Ph.D.s), and at most only 854 positions which might be filled, less than three hundred of which were classed as "reasonably firm"-that is, not hinging on the question of whether maximum budget and staffing requests were met. And only 149 of the "reasonably firm" slots were described as leading to permanent, fulltime positions.-AHA Professional Register 2:1 (October 1972), introduction.

3. Richard M. Gummere, Jr., "Toward a New Breed of Librarian," Wilson Library Bulletin 31:811 (Apr. 1967).

4. Richard W. Lyman, "New Trends in Higher Education: The Impact on the University Library," CRL 33:298-304 (July 1972). 